\title{
Soil Bulk Density as Influenced by Grazing Intensity and Soil Type on a Shortgrass Prairie Site
}

\author{
BRUCE P. VAN HAVEREN
}

\section{Abstract}

Soil bulk densities were measured on 2 soil groups under 3 grazing intensities on shortgrass prairie in northeastern Colorado. On coarse-textured soils, soil bulk density means of the 3 grazing treatments were not significantly different. On fine-textured soils, average bulk density in the heavily grazed pasture was $13.4 \%$ and $11.8 \%$ higher than the lightly grazed and moderately grazed pastures, respectively. For both soil groups combined, bulk density on the heavily grazed pasture was only $6 \%$ higher than on the lightly grazed pasture. A significant grazing intensity $\times$ soil texture interaction was present, indicating that soil compaction from grazing occurred primarily on fine-textured soils on the study site.

Interest in rangeland hydrology, particularly the effects of grazing on soil and water processes, has intensified during the past several years. The potential for soil compaction is an especially important concern of wildland managers.

Several reviews (Gifford and Hawkins 1976, American Society of Civil Engineers 1975, Heady et al. 1976) and a recent book (Branson et al. 1981) have summarized the literature on the subject of rangeland hydrology. These reviews all offer conclusive evidence that trampling and vegetation removal by grazing animals influence surface watershed characteristics and runoff potential.

Soil compaction has important hydrologic implications in terms of reduced infiltration rates, impacts on plant growth, and increases in runoff and erosion potentials (Orr 1975, Gifford et al. 1977).

Lull (1959) made a thorough review of soil compaction on forest and rangelands. He calculated the static ground pressures exerted by mature cattle to be $24 \mathrm{lb}$ per square inch. However, during movement pressures may exceed this amount by $4 \times$ as the animal's weight is distributed from one hoof to another. Lull cited several studies that showed significantly increased bulk densities under heavy grazing. Later, Reed and Peterson (1961) found significantly higher bulk densities under heavy grazing compared to light grazing on both sandy loam and clay sites in the Northern Great Plains. In a study also conducted on the Northern Great Plains, Rauzi and Hanson (1966) found that differences between bulk densities of silty clay soils on heavily, moderately, and lightly grazed pastures were all highly significant. In a study in northeastern Utah, Laycock and Conrad (1967) found no measurable compaction due to grazing on loam and clay loam soils, and concluded that conflicting results from bulk density studies are due to varying soil and moisture conditions. They stressed that bulk density was significantly correlated with soil-water content and warned that soilwater conditions should be as homogeneous as possible when bulk density is used to compare effects of grazing treatments on soil

\footnotetext{
Author is hydrologist, Bureau of Land Management, U.S. Department of the Interior, Denver Federal Center, Lakewood, Colorado 80225.

The data collection portion of the research reported here were supported in part by the National Science Foundation Grant GB-F824 to the U.S. IBP Grassland Biome Program, Colorado State University, Fort Collins.

Manuscript received September 1, 1981.
}

compaction. As pointed out by Lull (1959), more force is needed to compact a dry soil than to compact the same soil when wet. According to Reynolds and Packer (1963) soils with large clay fractions compact the easiest. Lull (1959) concluded that mediumtextured and well-aggregated soils had the potential for the greatest compaction because of well distributed particle-size distributions. None of the studies reviewed by the author attempted to analyze soil bulk density variance on the basis of both soil texture and grazing intensity. However, Lull (1959) did refer to a possible interaction between soil texture and compaction potential.

Galbraith (1971), in a study also cond ucted at the Central Plains Experimental Range, reported finding a significant bulk density difference between nongrazed and heavily grazed sites on the Ascalon soil series. The heavily grazed sites showed a $12 \%$ increase in bulk density over the nongrazed sites.

The objective of this paper was to explore the effect on soil bulk density of three different grazing intensities and two soil groups.

\section{Study Area and Methods}

\section{Description of Study Ares}

This study was conducted at the Central Plains Experimental Range near Nurin, Colo., approximately 45 miles northeast of Fort Collins, Colo. (Fig. 1). Average annual precipitation for the Central Plains Experimental Range is 12 inches. The major soils on the study area included Ascalon sandy loam, Shingle loam, ShingleRenohill complex, Renohill sandy loam, and Nunn loam.

Vegetation on the study site is characterized by blue grama (Bouteloua gracilis) and buffalograss (Buchloe dactyloides), which are the dominant forage grasses. Red threeawn (Aristida longiseta) and other common mesic grasses are scattered throughout the lightly and moderately grazed pastures. Annual and perennial forbs are also found throughout the study area, but comprise only a minor part of the flora.

This study was concentrated in 3 adjacent pastures, each 320 acres in size. Cattle stocking rates averaged 4.1, 3.1, and 1.8 acres per yearling heifer per month for the lightly, moderately, and heavily grazed pastures, respectively, for 30 consecutive years prior to this study. Season of use was approximately May 1 to October 31 (Dyck and Bement 1971).

\section{Sampling Procedures}

In each pasture, a single straight-line transect was located perpendicular to the main axis of the dry swales and located in such a way that each transect crossed all the major soil types in that pasture (Fig. 2). Sampling points were spaced $25 \mathrm{~m}$ apart on each of the transects, resulting in approximately 20 samples per transect. Bulk density sampling was performed in midsummer when the soil surface was uniformly dry across all soil types and all grazing treatments.

The soil bulk density samples were collected by means of a truck-mounted hydraulic coring device with a specially designed 


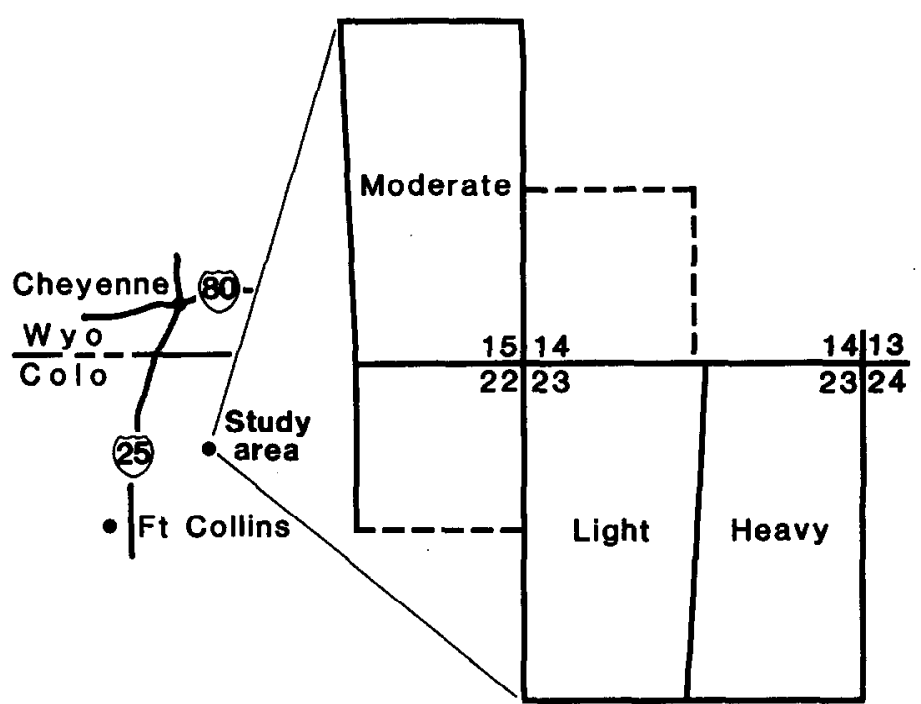

Fig. 1. Map of study area within the Central Plains Experimental Range, northeastern Colorado.

coring tube containing a sleeve of aluminum cyclinders of known volume. Undisturbed cores could be extracted from any desired depth. A review of the available literature suggested that for studies of soil compaction by animal traffic, samples should be taken from the surface $1 \mathrm{in} .(2.5 \mathrm{~cm})$ of the mineral fraction (Lull, 1959). The bulk density samples were $50 \mathrm{~cm}^{3}$ in volume, and taken from the top $2.5 \mathrm{~cm}$ of the mineral soil. Standard methods of sample handling and laboratory analysis were followed as prescribed by Black (1965).

\section{Data Analysis}

The bulk density samples were split into 2 different soil groups.
Table 1. Soll bulk dendity means ( $8 / c e$ ) for the 3 grazing treatments and 2 soil textural groups.

\begin{tabular}{lcccc}
\hline & \multicolumn{4}{c}{ Grazing intensity } \\
\cline { 2 - 5 } Soil group & Heavy & Moderate & Light & Average \\
\hline Coarse & 1.38 & 1.45 & 1.38 & 1.41 \\
Fine & 1.52 & 1.36 & 1.34 & 1.43 \\
Average & 1.45 & 1.42 & 1.37 & 1.41 \\
\hline
\end{tabular}

All samples taken from the Nunn loam, Shingle-Renohill complex, and Shingle loam soils were considered to be fine-textured soils. All other samples were classified as coarse-textured soils.

Using a two-way analysis-of-variance (AOV) procedure (STAT3IV Program, Colorado State University Computer Center), bulk density means were tested for differences between both grazing intensities and soil type. Subsequently, a single AOV test was run for each soil type to test the differences in bulk density between grazing treatments.

\section{Results and Discussion}

The soil bulk density results are shown in Table 1 . The two-way AOV showed a significant grazing treatment effect at the $95 \%$ level. Combining all the soils, heavy grazing was $6 \%$ higher than light grazing. The single AOV performed on the fine-textured soils showed the bulk density means were significantly ( $95 \%$ level) heterogeneous. Tukey's w-procedure from Sokal and Rohlf (1969) was run to clarify the heterogeneity. On the fine-textured soils, heavy grazing was significantly (13.4\%) greater than light grazing and significantly $(11.8 \%)$ greater than moderate grazing. There was no differences between light and moderate grazing. Soil bulk density means for the course-textured soils for the 3 grazing treatments were not significantly different. Also, there were no bulk density differences between coarse-textured soils and fine-textured soils with all grazing intensities included. The two-way AOV indicated a
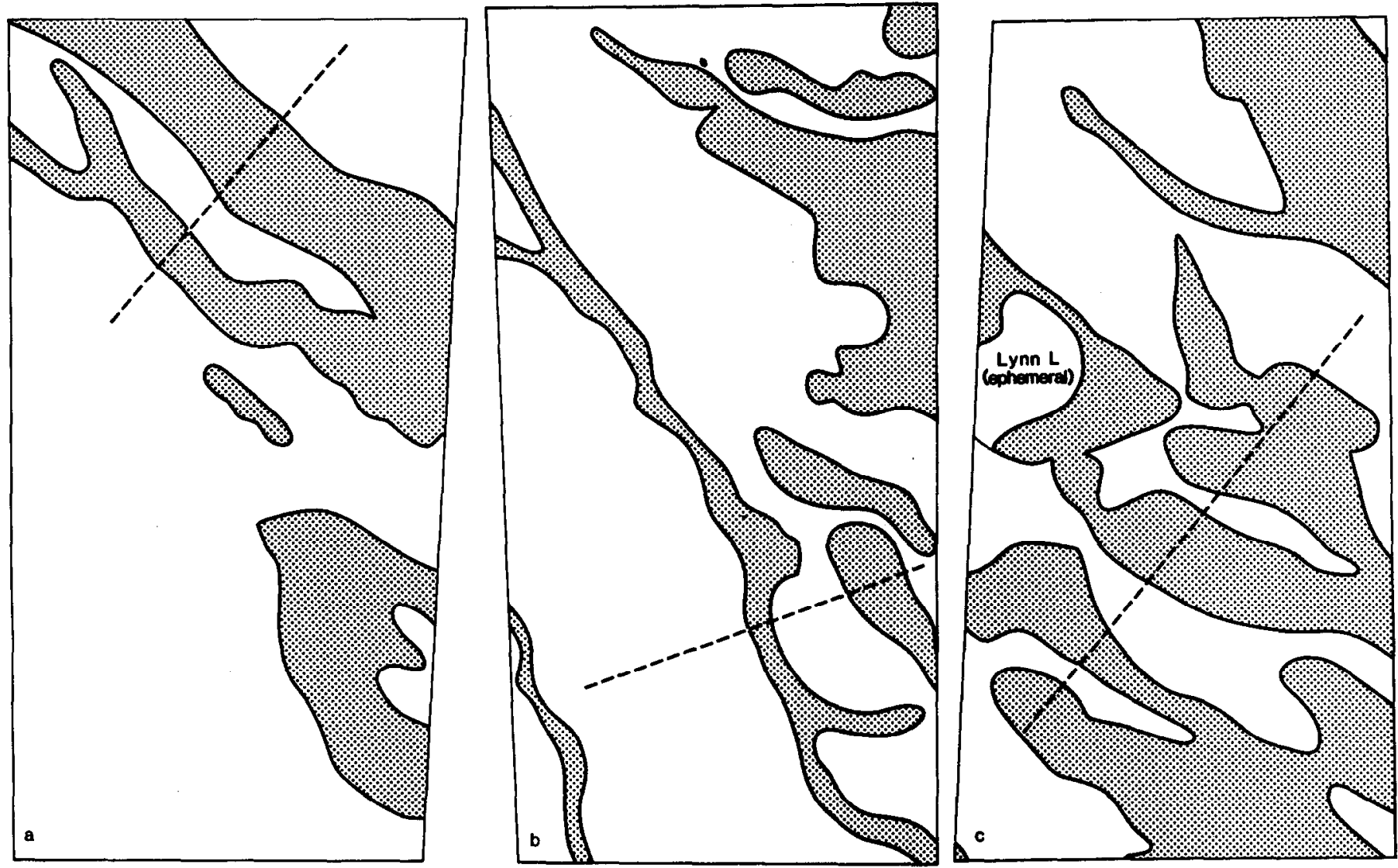

Fig. 2. Light (a), moderate (b), and heavily-grazed (c) pastures with their associated sampling transects. Shaded area indicates fine-textured soils. 


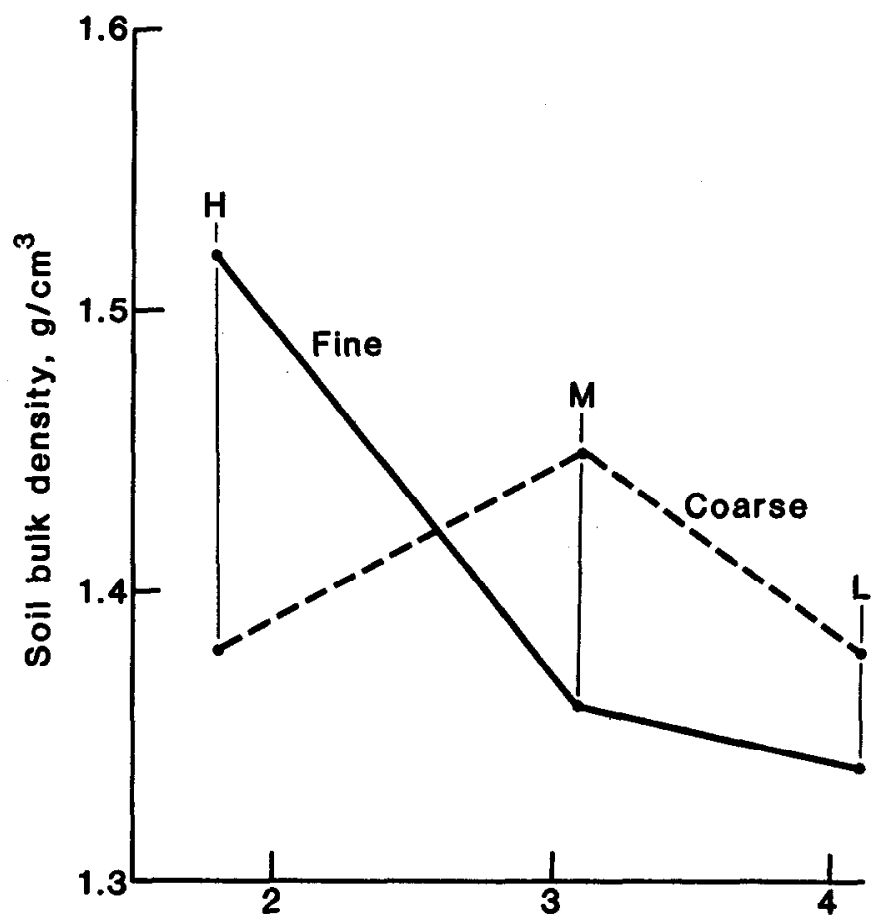

Grazing intensity, acre/yearling heifer/month

Fig. 3. Soil bulk density means for heavy $(H)$, moderate $(M)$, and light $(L)$ grazing intensity on two soil groups.

soil type $\times$ grazing intensity interaction significant at the $95 \%$ level. This interaction is shown graphically in Figure 3.

\section{Conclusions and Management Implications}

In this study the effect of grazing intensity on soil bulk density depended highly on soil type. Coarse-textured soil bulk densities were not affected by grazing intensity. Bulk densities on finetextured soils increased with grazing pressure. . As there were no statistically significant differences in bulk density between light and moderate grazing, both soil groups could support moderate grazing with no compaction effect.

Although Orr (1975) stated that bulk density is not necessarily a good indicator of infiltration, several prior studies have indicated the opposite. For Packer $(1953,1963)$ and Rauzi and Hanson (1966), infiltration rate was highly correlated with soil bulk density. Meeuwig (1965) reported that for subalpine range in Central Utah, infiltration capacity was influenced primarily by soil bulk density and noncapillary porosity. The summary data presented by Dortignac and Love (1961) also indicate a relationship between bulk density and infiltration rate.

Rauzi and Smith (1973) collected infiltration data on the Central Plains Experimental Range. They concluded that during the first 10 minutes of the infiltration process only the effect due to soils was significant. After 15 minutes of infiltration, grazing influences were detectable. After 20 minutes, soil and grazing effects were equally important. After 30 minutes, the interaction between grazing intensity and soil type was important. These results, compared with those reported in the present study, indicate a strong relationship between soil bulk density and infiltration.

The land management implications of this study and prior soil compaction studies are quite clear. Significant soil compaction may occur on rangeland soils at certain grazing intensities. The degree of soil compaction, as measured by bulk density, depends on the texture of the soil as well as on the water content of the soil at the time of grazing and the percentage of organic matter in the surface soil. For the Central Plains Experimental Range, soil compaction is more likely to occur on fine-textured soils in heavily grazed pastures. By inference, infiltration rates could likely be affected similarly.

\section{Literature Cited}

American Society of Clvil Engineers. 1975. Watershed management. Proc. Symp. on Watershed Manage., Logan, Utah.

Black, C.A. (ed.). 1965. Methods of soil analysis, Part I. ASA Monogr. No. 9, Amer. Soc. of Agron., Inc., Madison, Wis.

Branson, F.A., G.F. Gifford, K.G. Renard, and R.F. Hadley, 1981. Rangeland hydrology. Kendall/Hunt Publ. Co., Dubuque, lowa.

Dortignac, E.J., and L.D. Love. 1961. Infiltration studies on ponderosa pine ranges of Colorado. USDA For. Serv., Rocky Mountain Forest and Range Exp. Station Paper No. 59.

Dyck, G.W., and R.E. Bement. 1971. Herbage growth rate, forage intake, and forage quality in $\mathbf{1 9 7 0}$ on heavily and lightly grazed blue grama pastures. U.S. International Biological Program Grasslands Biome, Tech. Rep. No. 94 .

Galbraith, A.F. 1971. The soil water regime of a shortgrass prairie ecosystem. Ph.D. Diss., Colorado State Univ., Fort Collins.

Gifford, G.F., R.H. Faust, and G.B. Coltharp. 1977. Measuring soil compaction on rangeland. J. of Range Manage. 30:457-460.

Gifford, G.F., and R.H. Hawkins. 1976. Grazing systems and watershed management-a look at the record. J. Soil and Water Cons. 31:281-283.

Heady, H.F., D.F. Falkenborg, and J.P. Riley (eds.). 1976. Watershed management on range and forest lands. Proc. 5th Workshop of U.S./Australia Rangelands Panel. Utah Water Res. Lab., Logan, Utah.

Laycock, W.A., and P.W. Conrad. 1967. Effect of grazing on soil compaction as measured by bulk density on a high elevation cattle range. J. Range Manage. 20:136-140.

Lull, H.W. 1959. Soil compaction on forest and rangelands. USDA Forest Service Misc. Pub. No. 768.

Meeuwig, R.0. 1965. Effects of seeding and grazing on infiltration capacity and soil stability of a subalpine range in central Utah. J. of Range Manage. 18:173-180.

Orr, H.K. 1975. Recovery from soil compaction on bluegrass range in the Black Hills. Trans. Amer. Soc. Agr. Engrs. 18:1076-1081.

Packer, P.E. 1953. Effects of trampling disturbance on watershed condition, runoff, and erosion. J. of For. 51:28-31.

Packer, P.E. 1963. Soil stability requirements for the Gallatin elk winter range. J. of Wildlife Manage. 27:401-410.

Rauzi, F., and C.L. Hanson. 1966. Water intake and runoff as affected by intensity of grazing. J. Range Manage. 19:351-356.

Raudi, F., and F.M. Smith. 1973. Infiltration rates: Three soils with three grazing levels in northeastern Colorado. J. Range Manage. 26:126-129.

Reed, M.J., and R.A. Peterson. 1961. Vegetation, soil, and cattle responses to grazing on Northern Great Plains range. USDA Forest Service Tech. Bull. No. 1252.

Keynolds, H.G., and P.E. Packer. 1963. Effects of trampling on soil and vegetation. p. 116-122. In: Range Research Methods, USDA Misc. Pub. 940.

Sokal, R.R., and J.F. Rohlf. 1969. Biometry: the principles and practices of statistics in biological research. W.H. Freeman \& Co., San Francisco, Calif. 